\title{
Squarticles as the nanoantidotes to sequester the overdosed antidepressant for detoxification [Corrigendum]
}

\author{
Chen $\mathrm{CH}$, Huang $\mathrm{TH}$, Elzoghby $\mathrm{AO}$ et al. Int $J$ \\ Nanomedicine. 2017;12: 8071-8083.
}

The authors missed to mention a grant in the

Acknowledgments section of the paper.

On page 8082, the Acknowledgments should read as follows:

\section{Acknowledgments}

The authors are grateful to the Ministry of Science and Technology of Taiwan (MOST-105-2320-B-182010-MY3) and Chang Gung Memorial Hospital (CMRPD1F0231-3 and CMRPG6G0221) for the financial support.

\section{Publish your work in this journal}

The International Journal of Nanomedicine is an international, peerreviewed journal focusing on the application of nanotechnology in diagnostics, therapeutics, and drug delivery systems throughout the biomedical field. This journal is indexed on PubMed Central, MedLine, CAS, SciSearch ${ }^{\mathbb{R}}$, Current Contents ${ }^{\mathbb{R}} /$ Clinical Medicine,
Journal Citation Reports/Science Edition, EMBase, Scopus and the Elsevier Bibliographic databases. The manuscript management system is completely online and includes a very quick and fair peer-review system, which is all easy to use. Visit http://www.dovepress.com/ testimonials.php to read real quotes from published authors. 